\title{
Primary pulmonary hypertension and fenfluramine use
}

François Brenot, Philippe Herve, Patrick Petitpretz, Florence Parent, Pierre Duroux, Gérald Simonneau

\begin{abstract}
Not all the risk factors for primary pulmonary hypertension (PPH) are known. Appetite suppressants, including fenfluramine derivatives, are strongly suspected aetiological agents.

In a 5 year retrospective study fenfluramine use was evaluated among patients referred to a medical centre specialising in the management of PPH. Fifteen (20\%) of 73 patients with PPH had used fenfluramine: all of them were women and in $10(67 \%)$ there was a close temporal relation between fenfluramine use and the development of exertional dyspnoea. Initial right heart catheterisation in the 15 women showed severe resting pulmonary hypertension (mean (SD)) with pulmonary artery pressure (PAP) 57 (9) $\mathrm{mm} \mathrm{Hg}$, cardiac index 2.1 (0-5) $1 / \mathrm{min} / \mathrm{m}^{2}$, and pulmonery vascular resistance (PVR) 29 (10) $\mathrm{U}^{\mathrm{m}} \mathrm{m}^{2}$. Shortterm epoprostenol infusion produced a significant vasodilator response in 10 patients (mean fall in PVR 24 (15\%) comperred with control values). Three fenfluramine users with PPH showed spontaneous clinical and haemodynamic improvement 3, 6 and 12 months after dirug withdrawal but there was no significant difference in overall survival (transplant recipients excluded) between fenfluramine users and controls. Histological examination of lung tissue from five women who had used fenfluramine and 22 controls, with PPH showed features typical of advanced plexogenic pulmonary arteriopathy in all.
\end{abstract}

These results do not accord with earlier reports that PPH associated with fenfluramine is less severe and has a better outcome. Fenfluramine may be one aetiological agent that can precipitate or hasten the development of PPH. The results of a European case-control study should give new insights into risk factors for PPH and the cause and effect relation with fenfluramine.

(Br Heart f 1993;70:537-541)

Primary pulmonary hypertension ( $\mathrm{PPH}$ ) is a devastating disease, with an unknown pathogenesis. However, there is evidence that some aetiological factors can influence the expression of the disease in "susceptible" individu- als. ${ }^{1}$ These factors include appetite suppressant drugs, which have been strongly implicated since the 1960 s, because of an outbreak of PPH in Western Europe related to the intake of aminorex fumarate..$^{2-4}$ In sporadic cases of PPH associated with the use of fenfluramine derivatives reported since then remission was supposed to be common and survival better than in PPH in general. ${ }^{5-12}$ Consumption of appetite suppressants, mainly dexfenfluramine, has increased dramatically in European countries over the past 5 years, generally by women aged $20-60 . .^{13}$ Since 1988 when we saw our first case of $\mathrm{PPH}$ that was associated with fenfluramine use we have evaluated the proportion of "ever users" of fenfluramine among patients referred to our institution for PPH. Their haemodynamic function, clinical outcome, and survival were compared with those of PPH patients with no history of fenfluramine use who were referred during the same period.

\section{Patients and methods}

PATIENTS

Pulmonary hypertension was defined as a mean resting pulmonary artery pressure $>25$ $\mathrm{mm} \mathrm{Hg}$ during right heart catheterisation, with a mean pulmonary wedge pressure below $12 \mathrm{~mm} \mathrm{Hg.}{ }^{14}$ Potential causes of secondary pulmonary hypertension were excluded on the basis of previously defined criteria. $^{14}$ We excluded patients with PPH and concomitant portal hypertension or HIV infection (which may be another aetiological agent in $\mathrm{PPH}){ }^{15}$

Among other disease states and risk factors known to be associated with $\mathrm{PPH}^{14}$ we paid special attention to a history of the use of appetite suppressant drugs, especially fenfluramine derivatives (dl-fenfluramine or dexfenfluramine or both), and their effects on the clinical course of PPH (onset and worsening or improvement after withdrawal of the drug). At the time of first evaluation ever users of fenfluramine were classified as current or previous users: current users were those patients in whom symptoms suggestive of PPH had appeared or worsened during fenfluramine use; previous users were patients whose symptoms developed after fenfluramine use stopped and included "recent users" (whose symptoms occurred less than a year after the end of treatment) and "remote users" (whose symptoms began more than one year after the end of fenfluramine use). 
Patients were routinely asked whether they had also used other appetite suppressant drugs (amphetamine derivatives).

\section{HAEMODYNAMIC MEASUREMENTS}

A complete set of baseline haemodynamic data was obtained for each patient, during right heart catheterisation performed with a 7F triple lumen floatation thermodilution catheter (Edwards Swan-Ganz, Baxter Corporation). All measurements were made while patients were supine, breathing room air, and not taking vasodilating or inotropic drugs for at least 36-48 hours. Cardiac output was measured in triplicate by the thermodilution technique. The pulmonary vascular resistance index was calculated as the ratio of mean pulmonary artery pressure to cardiac index (cardiac output divided by body surface area). The heart rate was monitored continuously. Mean systemic artery pressure was measured with an external automatic sphygmomanometer (Dinamap Monitor, Critikon).

Most patients were tested with intravenous epoprostenol (prostacyclin, $\mathrm{PgI}_{2}$ ), which is a potent pulmonary vasodilator used to detect the potential for pulmonary vasodilatation. ${ }^{16} 17$ The dose of epoprostenol (Flolan, Wellcome) was increased by $2 \mathrm{ng} / \mathrm{kg} / \mathrm{min}$ every $10 \mathrm{~min}$ utes from $5 \mathrm{ng} / \mathrm{kg} / \mathrm{min}$ to a maximum dose of $10 \mathrm{ng} / \mathrm{kg} / \mathrm{min}$. The infusion was stopped immediately if systemic blood pressure dropped by more than $30 \%$ or if heart rate rose by more than $50 \%$ compared with control values and/or if side effects precluded a further increase in dosage. ${ }^{16}$ Significant dilatation during infusion was defined as a decrease in pulmonary vascular resistance (PVR) of at least $20 \%$ of the mean of 2 or 3 baseline measurements.

\section{STATISTICAL ANALYSIS}

Numerical results are expressed as means (SD) and ranges. Haemodynamic variables in patients in the fenfluramine and control groups were compared by the Wilcoxon rank sum test. The paired Student's $t$ test was used for within-group comparisons of PVR before and during epoprostenol infusion. In fenfluramine users and in controls we estimated survival from first catheterisation in our hospital till the end of the follow up period (date of most recent information on the patient or death) by the Kaplan-Meier product-limit method. Lung or heart-lung transplant recipients were excluded from the survival analysis. Differences in mean survival time were tested by the $\log$ rank test. A value of $p<0.05$ was regarded as statistically significant.

\section{Results}

Over a period of 60 months 105 patients with PPH were referred to our hospital for diagnostic and therapeutic evaluation (vasodilator testing or lung transplantation or both). Thirteen patients with associated portal hypertension and 19 with HIV infection were excluded: Fifteen of the 73 remaining PPH patients were ever users of fenfluramine and 58 had no history of fenfluramine use.

The 15 ever users of fenfluramine were all women (mean age 42 (10) range 20-54). All had used fenfluramine for at least three months (mean $15(20)$, range 3-61 months) at the recommended dose of $30 \mathrm{mg}$ per day for dexfenfluramine or $60 \mathrm{mg}$ to $120 \mathrm{mg}$ per day for dl-fenfluramine. Most ever users of fenfluramine (11/15) had taken dexfenfluramine (exclusively in eight) whereas three had used a combination of both derivatives. The four remaining patients had used only dl-fenfluramine.

Nine patients were regarded as current users at the time of diagnosis. Four complained of breathlessness while on fenfluramine therapy, which had been started 23 (21) months earlier. The five other current users, who developed dyspnoea on exertion 7 (4) months before fenfluramine use, became worse during treatment.

Four of the six patients regarded as previous users were "recent users" in whom symptoms developed less than one year after the end of treatment ( 1 to 11 months). Two other patients were remote users of fenfluramine and had stopped taking the drug 39 and 250 months before onset of $\mathrm{PPH}$ symptoms.

At the time of first evaluation in our hospital fenfluramine ever users had severe PPH (table 1) and most patients were in New York Heart Association functional class III or IV. For both groups, baseline haemodynamic findings showed severe precapillary pulmonary hypertension with decreased cardiac index at rest and an increase in pulmonary vascular resistance index up to six times greater than normal values (table 2 ). The effects of short-term infusion of epoprostenol in fenfluramine users were compared with those in the 53 of the 58 control patients (table 2): the proportion of responders to epoprostenol was higher in the fenfluramine group but not significantly. The level in the vasodilator response during challenge with epoprostenol was also similar in the two groups. No serious adverse events were reported.

Table 3 shows the outcome and follow up of fenfluramine users with $\mathrm{PPH}$ classified

Table 1 Clinical characteristics (mean (SD)) of the 15 fenfluramine users with PPH at the time of first evaluation

\begin{tabular}{lc}
\hline Characteristic & Mean(SD) \\
\hline Age (y) & $42(10)$ \\
Sex (f:m) & $15 / 0^{\star}$ \\
PPH Symptoms: & \\
Time between onset of symptoms and & $20(14)$ \\
diagnosis (mnth) & $5(33)$ \\
Functional class (NYHA) & $10(67)$ \\
I or II (n (\%)) & $6(40)$ \\
III or IV (n (\%)) & $6(40)$ \\
Syncope or near-syncope (n (\%)) & $2(13)$ \\
Chest pain (n (\%)) & $5(33)$ \\
Haemoptysis (n (\%)) & $3(20)$ \\
Right ventricular insufficiency (n (\%)) & $2(13)$ \\
Associated conditions: & $3(20)$ \\
Raynaud's phenomenon (n (\%)) & \\
Antinuclear antibody titre >1/80 (n (\%)) & \\
Migraines (n (\%)) & \\
\hline
\end{tabular}

NYHA, New York Heart Association. `Ratio. 
Table 2 Haemodynamic findings (mean (SD)) in fenfluramine users with PPH at first catheterisation

\begin{tabular}{|c|c|c|c|c|c|c|c|}
\hline & $\begin{array}{l}R A P \\
(m m H g)\end{array}$ & $\begin{array}{l}P A P \\
(m m H g)\end{array}$ & $\begin{array}{l}P W P \\
\left(m m H_{g}\right)\end{array}$ & $\begin{array}{l}C I \\
\left(I / \min / m^{2}\right)\end{array}$ & $\begin{array}{l}P V R \\
\left(U / m^{2}\right)\end{array}$ & $\begin{array}{l}\% \text { decrease in PVR } \\
\text { during epoprostenol }\end{array}$ & $\begin{array}{l}\text { Responders/tested } \\
\text { to epoprostenol }\end{array}$ \\
\hline $\begin{array}{l}\text { Fenfluramine users }(n=15) \\
\text { Controls with PPH }(n=58)\end{array}$ & $\begin{array}{l}10(4) \\
\text { NS } \\
9(5)\end{array}$ & $\begin{array}{l}57(9) \\
\text { NS } \\
63(16)\end{array}$ & $\begin{array}{l}9(2) \\
\text { NS } \\
8(3)\end{array}$ & $\begin{array}{l}2 \cdot 1(0.5) \\
\text { NS } \\
2 \cdot 2(0.5)\end{array}$ & $\begin{array}{l}29(10) \\
\text { NS } \\
31(12)\end{array}$ & $\begin{array}{l}24(15) \\
\text { NS } \\
23(17)\end{array}$ & $\begin{array}{l}10 / 15 \\
\text { NS } \\
29 / 53\end{array}$ \\
\hline
\end{tabular}

Haemodynamic variables measured in patients at rest, breathing room air, with no supportive drug. RAP, mean right atrial pressure; PAP, mean pulmonary artery pressure; PWP, mean pulmonary wedge pressure; CI, cardiac index, PVR, pulmonary pressure; PAP, mean pulmonary artery pressure; PWP, mean pulmonary
vascular resistance index. For definition of responders see methods section.

Table 3 Outcome and follow up of the 15 fenfluramine users with PPH

\begin{tabular}{|c|c|c|c|c|}
\hline Patient No & Age/sex & $\begin{array}{l}\text { Date of PPH } \\
\text { diagnosis }\end{array}$ & Outcome (clinical and haemodynamic) & $\begin{array}{l}\text { Follow ipp to } \\
\text { December } 1992\end{array}$ \\
\hline $\begin{array}{r}1 \\
2 \\
3 \\
4 \\
5 \\
6 \\
7 \\
8 \\
9 \\
10 \\
11 \\
12 \\
13 \\
14 \\
15\end{array}$ & $\begin{array}{l}42 / F \\
51 / F \\
43 / F \\
43 / F \\
34 / F \\
44 / F \\
54 / F \\
20 / F \\
29 / F \\
35 / F \\
36 / F \\
52 / F \\
47 / F \\
54 / F \\
49 / F\end{array}$ & $\begin{array}{l}\text { Sept } 88 \\
\text { Nov } 88 \\
\text { Jan } 89 \\
\text { Nov } 89 \\
\text { June } 90 \\
\text { April } 91 \\
\text { May } 91 \\
\text { July } 91 \\
\text { Sept } 91 \\
\text { Oct } 91 \\
\text { Oct } 91 \\
\text { April } 92 \\
\text { April } 92 \\
\text { Sept } 92 \\
\text { Oct } 92\end{array}$ & $\begin{array}{l}\text { Improved (6 mnth). Worsened at } 2 \text { years (WL Nov 90) } \\
\text { Improved ( } 3 \text { mnth) } \\
\text { Worsened (WL Jan 89) } \\
\text { Worsened (WL Jan 90) } \\
\text { Stabilised } \\
\text { Worsened (WL Aug 92) } \\
\text { Worsened ( } \\
\text { Improved (12 mnth) } \\
\text { Worsened (WL April 92) } \\
\text { Worsened (WL Feb 92) } \\
\text { Worsened (WL Dec 91) } \\
\text { Stabilised } \\
\text { Worsened (WL April 92) } \\
\text { Stabilised } \\
\text { Stabilised }\end{array}$ & $\begin{array}{l}\text { Dead May } 91 \text { (RVI) } \\
\text { Alive Dec 92 } \\
\text { Dead March } 89^{\star} \\
\text { Alive Sept } 92 \\
\text { Alive May } 92 \\
\text { Alive Dec } 92 \\
\text { Dead Nov } 91^{\star} \\
\text { Alive Dec } 92 \\
\text { Alive Dec } 92 \\
\text { Alive Dec } 92 \text { (HLT Feb 92) } \\
\text { Alive Dec } 92 \\
\text { Alive Dec } 92 \\
\text { Alive Dec } 92 \text { (HLT Aug 92) } \\
\text { Alive Dec } 92 \\
\text { Alive Dec } 92\end{array}$ \\
\hline
\end{tabular}

HTL, heart-lung transplantation; RVI, right ventricular insufficiency; WL, lung transplantation waiting list and date of registration. * Sudden death.

according to the date of PPH diagnosis. Three of them (cases 1, 2, and 8) showed clinical and haemodynamic improvement after withdrawal of the drug. Two of these three patients (cases 1 and 2 ) had a history of long-term exposure to both fenfluramine derivatives lasting 45 and 52 months respectively. They both were current fenfluramine users (for 42 and 40 months respectively) when they complained of exertional dyspnoea. In patient 1 catheterisation 6 months after withdrawal showed that PVR had fallen by more than $50 \%$ since the first catheterisation (from 24 to $10 \mathrm{U} / \mathrm{m}^{2}$ ). Her condition remained stable for two years but then worsened. She denied exposure to fenfluramine and she died of severe PPH while awaiting heart-lung transplantation. Patient 2 also showed a considerable spontaneous haemodynamic improvement 3 months after fenfluramine withdrawal, with a fall in PVR from $19 \mathrm{U} / \mathrm{m}^{2}$ to $10 . \mathrm{U} / \mathrm{m}^{2}$. She is still doing well 4 years later, with moderate resting pulmonary hypertension and definitely abnormal haemodynamic function during exercise catheterisation. A third fenfluramine user (patient 8) also showed spontaneous improvement after drug withdrawal with a decrease in PVR from $35 \mathrm{U} / \mathrm{m}^{2}$ to $15 \mathrm{U} / \mathrm{m}^{2}$ between the initial catheterisation and one 12 months later. The remaining 12 patients showed either clinical and haemodynamic stabilisation or deterioration despite fenfluramine withdrawal.

Eight of the 15 fenfluramine users and 30 of the controls joined a lung or heart-lung transplantation waiting list. Two (patients 10 and 13) had successful heart-lung transplantation and were excluded from survival analysis as were the 15 transplant recipients in the control group. There was no significant difference in overall survival (figure) between the fenfluramine users and the controls with about $55 \%$ and $42 \%$ survival respectively at 3 years. Histological studies were performed in five fenfluramine users (three necropsies, two heart and lung transplants). They showed features typical of advanced plexogenic pulmonary arteriopathy that resembled the pathologic findings in lung tissue obtained from 22/58 controls (seven necropsies, 15 heart and lung transplants).

\section{Discussion}

The issue of whether or not appetite suppressant use is associated with the development of PPH arose when the incidence of the disease suddenly and considerably increased in the 1960s in Western Europe. ${ }^{2-4}$ This epidemic was closely related to use of the appetite suppressant drug aminorex fumarate. Though laboratory animals did not develop pulmonary hypertension during chronic administration of aminorex, the cause-effect relation in humans was confirmed by epidemiological data. ${ }^{4}$ Since 1981 there have been 10 reports of cases of PPH associated with the use of the appetite suppressant drug fenfluramine. ${ }^{5-12}$ All

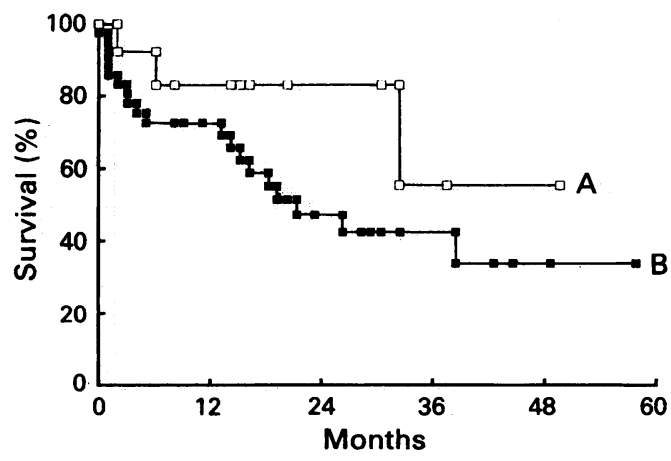

Comparison of overall survival in fenfluramine users $(A, n=13)$ and controls $(B, n=43)$. Two lung transplant recipients in group $A$ and 15 in group $B$ were excluded from survival analysis. Survival rates in the two patient populations were not significantly different (log rank test, NS). 
the patients were women (aged 26-58). Most of the reported cases $(8 / 10)$ were related to the use of dl-fenfluramine, ${ }^{5-10}$ whereas two other cases were linked to the more recently marketed dexfenfluramine..$^{11} 12$

We report 15 additional cases of PPH in which fenfluramine may have influenced the expression and/or outcome of the disease. Though our series is much smaller than the 1960s PPH outbreak related to aminorex it raises the question of an association between fenfluramine exposure and PPH. In our series the number of patients with $\mathrm{PPH}$ possibly related to fenfluramine use increased recently: two thirds of our cases were diagnosed between January 1991 and December 1992. This seems to parallel the increase in dexfenfluramine consumption in Europe. ${ }^{13}$ Because our hospital is a major referral centre for the management of PPH all our patients with PPH were referred for diagnosis and treatment and not because of fenfluramine exposure. The overall population of patients with PPH investigated in our institution over the past 4 years has remained stable at around 20 to 30 new cases per year. The proportion of fenfluramine users among current PPH patients was $20 \%$ of the overall patient population and $28 \%$ of all women (15/53). This rate is probably higher than the proportion of fenfluramine users among women of the same age in France.

Eight patients in the present series (four current and four recent users) developed exertional dyspnoea approximately 12 months after the start of treatment, a similar interval to that reported by Gurtner at the time of the aminorex epidemic ${ }^{2-4}$ and to previous reports of fenfluramine-related $\mathrm{PPH}$ cases of which $6 / 10$ were current or recent fenfluramine users when symptoms occurred. ${ }^{5-11}$ In the five remaining current users, who developed dyspnoea shortly before fenfluramine use, the influence of the drug seemed to be particularly obvious in two of them who definitely worsened after 2 months' exposure, with increased dyspnoea and nearsyncope on exertion. This suggests that fenfluramine may not only precipitate but may also hasten the course of the disease. A similar clinical course has already been reported in a patient with fenfluramine-related PPH who was rechallenged. ${ }^{5}$ The role of fenfluramine may be more questionable in the two remote users, though there are reports of two patients in whom symptoms developed 2 and 3 years respectively after fenfluramine use. ${ }^{68}$ Combination treatment with other appetite suppressants, which has been reported in series and individuals with appetite-suppressant-related $\mathrm{PPH},{ }^{314}$ was also noted in $6 / 15$ of our fenfluramine users. In at least $10 / 15$ $(67 \%)$ fenfluramine ever users in the present series there seemed to be a close temporal relation between the period of use and the development of $\mathrm{PPH}$, which was diagnosed shortly after onset or worsening of symptoms.

As in all previously reported cases of PPH associated with fenfluramine use $\mathrm{e}^{5-12}$ all our fenfluramine ever users were female. Though a female predominance is characteristic of $\mathrm{PPH}$, the sex ratio reported in PPH related to appetite suppressants is much higher than the commonly reported $2: 1$ value in "pure" $\mathrm{PPH} .{ }^{14} \mathrm{~A}$ likely explanation is that women are more likely than men to use appetite suppressants and are also believed to be more susceptible to pulmonary hypertension. ${ }^{1}$

In the Swiss epidemic the disease progressed more rapidly in the aminorex users than in the non-users and the mean time between onset of complaints and hospital admission was shorter. ${ }^{24}$ This was true of our fenfluramine users (20 (14) months) and non-users ( 31 (36) months) but the difference did not reach statistical significance $(p=$ 0.37). Haemodynamic findings during baseline catheterisation showed severe pulmonary hypertension as did earlier studies of fenfluramine-related $P P H . .^{5-12}$ No relation has ever been found between the total duration of the use of appetite suppressants and the degree of pulmonary hypertension, ${ }^{4}$ and we found no such relation in our patients. Two thirds of our patients showed a reversible component in pulmonary hypertension (vasodilatation in response to epoprostenol). The three fenfluramine users who showed spontaneous haemodynamic improvement after drug withdrawal showed the greatest vasodilatation in response to epoprostenol, with a decrease in PVR of approximately $45 \%$ of baseline values. These patients were current fenfluramine users at the time of diagnosis, and two of them had stopped taking the drug only a few days or weeks before catheterisation: thus their response to epoprostenol may have been measured when their pulmonary vascular tone was still increased by fenfluramine.

It has been suggested that patients with appetite-suppressant-related PPH have a better long-term course and survival than other patients with PPH..$^{3-4} 7$ Five of the 10 cases of fenfluramine-related PPH reported earlier definitely showed spontaneous clinical and haemodynamic remission (partial or complete) within 1-3 months after first catheterisation and withdrawal of the drug. ${ }^{5-6912}$ Better survival was also characteristic of the aminorex epidemic, ${ }^{46}$ though almost half died within the first 10 years of follow up. ${ }^{4}$ Half of the survivors were restudied several years after initial diagnosis and all showed a considerable increase in PVR during exercise catheterisation despite almost normal resting haemodynamic variables. ${ }^{4}$ This suggests persistence of underlying pulmonary arteriolar disease, as we found in our only fenfluramine user with a long lasting remission (case 2). Remission of PPH after drug withdrawal, however, was not the rule in most of the fenfluramine users we report and the idea of a better prognosis is not supported by their survival rate, which was not significantly better than that of the control PPH patients, who were evaluated and treated in the same manner and had comparable baseline clinical and haemodynamic characteristics.

The mechanisms responsible for pulmonary hypertension in patients using fenflu- 
ramine or other amphetamine-related appetite suppressants are unclear. Most of these drugs, including fenfluramine, are structurally related and their anorectic activity is attributable to the phenylethylamine molecule. ${ }^{18}$ They all have sympathomimetic and serotoninergic effects to various degrees: the latter involve blocking of cellular uptake and metabolism of serotonin, inhibition of monoamine oxidase activity and, more generally, release of large amounts of serotonin from cellular stores (platelets, nerve endings). ${ }^{18}$ Serotonin contracts isolated pulmonary arteries in dogs and humans ${ }^{19} 20$ and has a synergic effect with platelet-derived growth factor on vascular smooth muscle cell proliferation. ${ }^{21}$ Moreover, humans with PPH had much higher concentrations of free plasma serotonin than controls. This finding is probably related to increased serotonin release from platelets. ${ }^{22} 23$ Furthermore, a recent study in rats showed that high doses of fenfluramine can induce acute lethal pulmonary hypertension. ${ }^{24}$

Though this report of 15 new cases of PPH associated with fenfluramine use provides no definitive answers about a cause and effect relation, it suggests that fenfluramine influences the expression and outcome of primary pulmonary hypertension. The results of a long-term European case-control study should give new insights into the general risk factors for PPH development, including the relative risk associated with fenfluramine use.

We thank all respiratory physicians and cardiologists for referring patients; all nurses and other physicians of the departpud Lung Transplant

1 Voelkel NF, Weir EK. Etiologic mechanisms in primary pulmonary hypertension. In: Weir EK, Reeves JT, eds. Pulmonary vascular physiology and pathophysiology. Lung biology in health and disease. New York: M Dekker 1989;38:513-39.

2 Gurtner HP, Gertsch M, Salzmann C, Scherrer M, Stuck $P$, Wyss F. Häufen sich die primär vaskulären formen des chronischen cor pulmonale? Schweiz Med Wsch 1968;98:1579-89,1695-1707.

3 Gurtner HP. Pulmonary hypertension, "plexogenic pulmonary arteriopathy" and the appetite depressant drus aminorex: post or propter? Bull Eur Physiopath Resp 1979;15:897-923.
4 Gurtner HP. Aminorex pulmonary hypertension. In: Fishman AP, ed. The pulmonary circulation: normal and abnormal. Philadelphia: University of Pennsylvania Press, 1990;29:398-411.

5 Douglas JG, Munro JF, Kitchin AH, Muir AL, Proudfoot AT. Pulmonary hypertension and fenfluramine. $\mathrm{Br} \mathrm{Med}$ f $1981 ; 283: 881-3$.

6 Gaul G, Blazek G, Deutsch E, Heeger H. Ein fall von chronischer pulmonaler hypertonie nach Fenfluramineinahme. Wiener Klin Wschr 1982;22:618-21.

7 Loogen F, Worth H, Schwan G, Goeckenjan, Lösse B, Horstkotte $D$. Long term follow-up of pulmonary hypertension in patients with and without anorectic drug intake. Cor Vasa 1985;27:111-24.

8 McMurray J, Bloomfield P, Miller HC. Irreversible pulmonary hypertension after treatment with fenfluramine. monary hypertension after trea

9 Pouwels HMM, Smeets JLRM, Cheriex EC, Wouters EFM. Pulmonary hypertension and fenfluramine. Eur EFM. Pulmonary hyper

10 Fotiadis I, Apostolou T, Koukoulas A, Michelacakis N, Kremastinos D. Fenfluramine-induced irreversible pulmonary hypertension. Postgrad Med f 1991;67:776-7

11 Atanassoff PG, Weiss BM, Schmid ER, Tornic M. Pulmonary hypertension and dexfenfluramine. Lancet 1992;339:436.

12 Roche N, Labrune S, Braun JM, Huchon G. Pulmonary hypertension and dexfenfluramine. Lancet 1992;339: 436-7.

13 Dexfenfluramine. Lancet 1991;337:1315-6.

14 Rich S, Dantzker DR, Ayres SM, Bergofsky EH, Brundage BH, Detre KM, et al. Primary pulmonary brunertension. A national prospective study. Ann Intern Med 1987;107:216-23.

15 Polos PG, Wolfe D, Harley RA, Strange C, Sahn SA Pulmonary hypertension and human immunodeficiency virus infection. Two reports and a review of the literavirus infection. Two reports

16 Rubin LJ, Groves BM, Reeves JT, Frosolono M, Handel F, Cato AE. Prostacyclin-induced acute pulmonary vasodilatation in primary pulmonary hypertension. Circulation 1982;66:334-8.

17 Simonneau G, Hervé P, Petitpretz P, Girard P, Salmeron $S$, Escourrou $P$, et al. Detection of a reversible component in primary pulmonary hypertension: value of prostacyclin acute infusion [abst]. Am Rev Respir Dis 1986;133:223.

18 Pinder RM, Brogden RN, Sauryer PR, Speight TM, Avery GS. Fenfluramine: a review of its pharmacological properties and therapeutic efficacy in obesity. Drugs 1975;10:241-323.

19 McGoon MD, Vanhoutte PM. Aggregating platelets contract isolated canine pulmonary arteries by releasing 5-hydroxytryptamine. $₹$ Clin Invest 1984;74:828-33.

20 Boe J, Simonsson BG, Stahl E. Effect of histamine, 5-hydroxytryptamine and prostaglandins on isolated 5-hydroxytryptamine and prostaglandins on isol

21 Nemecek GM, Coughlin SR, Handley DA, Moskowitz MA. Stimulation of aortic smooth muscle cell mitogenesis by

22 Hervé $\dot{P}$, Launay JM, Drouet L, Scrobohaci ML Simonneau G, Duroux P. Significance of high plasma serotonin in primary pulmonary hypertension [abst]. Am Rev Respir Dis 1988;137:106.

23 Hervé P, Drouet L, Bosquet C, Launay JM, Rain B Simonneau G, et al. Primary pulmonary hypertension in a patient with a familial platelet storage pool disease. Am $\mathcal{Y}$ Med 1990;89:117-20.

24 Hunsinger RN, Wright $D$. A characterization of the acute cardiopulmonary toxicity of fenfluramine in the rat. Pharmacol Res 1990;22:371-8. 